\title{
Climax Theories and a Recommendation for Vegetation Classification-A Viewpoint
}

\author{
DONALD O. MEEKER, JR., AND DANIEL L. MERKEL
}

\section{Introduction}

Tansley (1920) reported, "The opinions and practices of synecologists in regard to the classification of vegetation appear superficially to be in as great a confusion today as they did 20 years ago..." One needs to spend little time discussing the subject to discover that Tansley's statement made 60 years ago still holds true today. This is indicated by Shimwell (1972), who reported that the classification of vegetation suffers greatly from overstatement, ambiguity, and inevitably some misinterpretation. After careful consideration of these statements, one may ask why we need classification? Fosberg (1967) pointed out that vegetation classification serves to facilitate the recording of information, to provide for intelligent discussion of vegetation, to aid in understanding the phenomenon itself, and to enable people to communicate vegetation information easily and unambiguously.

The purpose of this paper is to discuss one aspect of classification. This is the complexing viewpoint of climax theory.

\section{Why Climax?}

Why use any climax theory as the major criterion for a vegetation classification? The answer is not readily apparent.

Odum (1971) indicated that the degree of deviation from a theoretical climax can be measured and the factors responsible for the deviation can therefore be determined when there is a basic yardstick available for comparison. A vegetation classification based on climax establishes a basis for decision making and evaluating the effects of resource management. Clements (1936) viewed the relation between climax and classification this way: "Climax constitutes the major unit of vegetation and as such forms the basis for the natural classification of plant communities." Hall (1970) reported that the separation of climax and seral continuum gradients is essential for management, silvicultural guides, and field application of research results.

The climax concept is an accepted basis for many land management agencies and worldwide vegetation classification systems. For example, climax is used, in most cases, as the basis for the United Nations Educational, Scientific, and Cultural Organization (UNESCO 1973) vegetation classification. UNESCO serves as the pattern for the vegetation element of the Ecological Land Classification Framework for the United States (Driscoll et al. 1984). Climax is also used for USDA Soil Conservation Service range site descriptions (USDA SCS [Range Handbook] 1976), the USDI Bureau of Land Management soil-vegetation inventory (USDI BLM [SVIM], the USDI Bureau of Indian Affairs range site descriptions (USDI BIA 1958), and the USDA Forest Service range allotment analysis procedures (USDA FS [Manual 2200] 1979).

\footnotetext{
Donald O. Meeker, Jr., was formerly a range scientist with USDA Forest Service, Rocky Mountain Forest and Range Experiment Station. He is presently environmental engineer with Trapper Mining Inc., Craig, Colo. Daniel L. Merkel was range conservationist, USDA, Soil Conservation Service, Rocky Mountain Forest and Range Experiment Station, Fort Collins, Colo., in cooperation with Colorado State University. $\mathrm{He}$ is currently program leader for rangeland management, Extension Service, Washington, D.C

Manuscript was accepted March 21, 1984.
}

\section{Climax Concepts and Theory}

While there are numerous theories and versions of each, this manuscript explores 5 major climax theories: monoclimax, polyclimax, polyclimatic climax, climax pattern, and site climax. The 5 were chosen because of their ability to be of value to management. As a consequence, theories such as the dynamic functional concept (Odum 1969, Bazzaz 1979, and MacMahon 1980) were not considered, even though they are as worthy of consideration on the grounds of soundness of theory. It is the intent here to analyze these 5 theories and identify their basic differences. Once this has been done, the version that presents the best basis for a classification system can be recommended.

\section{The Monoclimax Theory}

The monoclimax theory, as developed by Clements $(1916,1936)$, is often described as the origin of dynamic ecology. The major concepts are succession and climax. Although the monoclimax theory has come under considerable attack and rejection by many, Cain (1939) stated that Clements has evolved a philosophy, a set of principles, and terminology to meet nearly every situation.

The major assumptions of the monoclimax theory are:

1. All successions of a region lead through time to the same adult organism (the climax) regardless of earlier site differences (Clements 1936).

2. Climatic factors determine the dominant species that can be present in a region, and completion results in selection of one or more species as the final dominants (Clements 1916).

3. Although climax is permanent because of its harmony with a stable habitat, the equilibrium is dynamic and not static. Superficial modifications may occur with the season, year, or cycle. However, these modifications, which are constantly at work, do not destroy the climax because they are within the fabric and limits of the climax.

The monoclimax theory proposes that every region has only 1 climax plant community toward which all are developing (Krebs 1972). In other words, Clements viewed the successional development of a xerosere and hydrosere that occurred under the same macroclimate as eventually ending in a similar mesophytic community. He also presents climate as the major factor to determine the climax community. The monoclimax theory views climax as a permanent dynamic community, not as a static condition. This theory accounted for the climax and seral unit hierarchy that Clements (1936) developed.

Although Clements believed that the climatic formation is the only climax of successional development (Clements 1916), he recognized succession may stop in practically any stage for a period of time for one reason or another. To deal with plant communities that did not conform to the climax type, he employed the terms disclimax, preclimax, postclimax, subclimax, and sereclimax (Weaver and Clements 1938).

Some criticisms of the monoclimax theory deal with the very basis of the hypothesis: that plant communities formed in an open water body and those developed on bare rock will eventually form 
a single climax community within a macroclimatically uniform region. One of the major reasons the hypothesis has lost acceptance is pointed out by DuRietz (1930). He described the contrast in vegetation on 2 soils that had developed from 2 different parent materials on level topography and under the same macroclimate. Although the successional development of the vegetation had been undisturbed since Tertiary, the contrast in vegetation betwcen the 2 soils was evident. This points out that differences between certain soils, due to parent material, may not be eliminated even in areas with level landscapes and adequate moisture relations.

While many reject the monoclimax theory, one must not overlook the service Clements provided the plant ecology field. Whittaker (1953) pointed out: "The Clementsian system had a fine design if its premises were granted; and for its erection Clements may rank as one of the truly creative minds of the field."

\section{The Polyclimax Theory}

Tansley (1939) is credited with developing the polyclimax theory to its full perspective. However, it was Moss (1913) who set the stage for its development after Cowles (1899, 1901) laid the basic foundation. The polyclimax theory states that there may be a number of different climax communities within a climatic region. Each climax unit can be in dynamic equilibrium with the local habitats and their controlling environmental factors. Thus, MuellerDombois and Ellenburg (1974) reported that a climax landscape consists of a mosaic of edaphic, topographic, or ecoclimatically different communities with one usually geographically dominant, the climatic climax.

Support for the polyclimax hypothesis (DuRietz 1930, Domin 1923, Daubenmire 1968, Gleason 1939, Tansley 1929) is due largely to the recognition of edaphic climaxes (Cain 1939). The polyclimax theory accepts a fire climax where naturally occurring fires periodically arrest the development of vegetation, permitting fireadapted species to dominate. The resulting plant community is termed disclimax (Daubenmire 1968).

Recognition of fire by the polyclimax theory differs little from the monoclimax theory. Clements recognized a plant community that was periodically arrested by fire as subclimax. Thus, on this point and others, the major difference between the monoclimax and polyclimax hypotheses is terminology (i.e., disclimax and subclimax, both being deviates).

Muller-Dombois and Ellenburg (1974) showed the correlation between the 2 theories more clearly by indicating that, "The more widely known polyclimax concept is still an offspring of the monoclimax concept insofar as it recognizes only one climatic climax in a macroclimatic region (namely the natural or nearnatural community on well-drained substrates) plus a number of other climax communities that are controlled primarily by topographic, edaphic, or other factor complexes."

Since the major difference between the 2 theories, poly and monoclimax, is semantics, it seems illogical to accept one and reject the other. However, Shimwell (1972) indicated that the polyclimatic theory has some advantages when he said, "It is infinitely simpler than the monoclimax theory which involves suppositions, climatic regulatory processes, and vegetation convergence in spite of environmental differences."

\section{The Polyclimatic Climax Theory}

Since the monoclimax theories recognize only 1 climatic climax, a new concept was developed, the polyclimatic climax. The polyclimatic climax theory was developed primarily by Tuxen (1933), Tuxen and Diemont (1937), and Ellenburg (1959). Although it is a modified version of the polyclimax theory, it has 1 major distinction. The polyclimatic climax recognizes that more than 1 climatic climax community can exist in a macroclimatic region.

Two major propositions of the polyclimatic climax theory are:

1. Any macroclimatic region may contain more than 1 climatic climax due to the different mature soil types that may occur in the region (Tuxen 1933).
2. The different mature soils, which may result from different parent material, show no indication of ever merging into 1 soil type. Thus, the climax plant communities that occupy these different mature soils also show no indication of ever merging into 1 climatic climax community (Mueller-Dombois and Ellenburg 1974).

One disadvantage of the polyclimatic climax theory, is that it is impossible for a plant community to be considered climax unless it occurs on a well-developed or mature soil. Thus, before a plant community can be considered climax, it must occur within a stable ecosystem. According to Mueller-Dombois and Ellenburg (1974), community stability must be seen as equal to stability in soil development and geomorphological development.

\section{The Climax Pattern Theory}

The climax pattern theory was developed by Whittaker (1951, 1953). According to Shimwell (1972) the climax pattern theory evolves around 3 major propositions on the nature and structure of climaxes and their relativity:

1. "The climax is a steady-state of community productivity, structure, and population, with the dynamic balance of its populations determined in relation to its site."

2. "The balance among populations shifts with change in environment, so that climax vegetation is a pattern of populations corresponding to the pattern of environmental gradients, and more or less diverse according to diversity of environments and kinds of populations in the pattern."

3. "Since whatever affects populations may affect climax composition, this is determined by, or in relation to, all factors of the mature ecosystem-properties of each of the species involved, climate, soil and other aspects of site, biotic interrelation, floristic and faunistic availability, chances of dispersal and interaction, etc. There is no absolute climax for any area, and climax composition has meaning only relative to position along environmental gradients and to other factors."

It is clear from these 3 propositions, that Whittaker rejected the basic units of vegetation which were an integral part of the monoclimax, polyclimax, and polyclimatic climax theories. This reflected Whittaker's view that no 2 stands of undisturbed vegetation are alike. $\mathrm{He}$, therefore, supported the individualist hypothesis of Gleason (1939) that vegetation occurs as a continuum rather than as discontinuous stands. Although the continuum theory (Curtis and McIntosh 1951) rejects vegetation classification into discrete communities, it does allow it to be arranged along a continuum according to the degree of similarity among the vegetation stands.

One method of determining the continuum is by gradient analysis which was developed extensively by Whittaker $(1951,1956$, 1967). It is, therefore, fitting that Whittaker's main approach to the definition of climax was via gradient analysis.

Another major distinction between the climax pattern theory and the monoclimax, polyclimax, polyclimatic climax theories is that it does not require geomorphological equilibrium. However, to accept the climax pattern theory, one has to reject the association concept, as used by Braun-Blanquet (1932) or Clements (1936), and consider vegetation as a continuum through gradient analysis.

\section{The (Site) Climax Theory}

Dyksterhuis (1949, 1958a) discussed a climax theory in relation to range site classification. The term "site climax" will be used to refer to this theory."

Dyksterhuis (1949) reported: "We accept products of mancaused erosion along with intrazonal and azonal soils as potentially stable soils or sites and consider the relatively stable plant community in equilibrium with such soils as climax. Summarily, the term climax as used here refers to climatic, edaphic, or physiographic climaxes and is usually synonymous with original vegetation." Therefore, Dyksterhuis, like Whittaker, views climax in a 
very fundamental aspect. The major difference between the site climax theory and the monoclimax, polyclimax, polyclimatic climax theories is that it does not require geomorphological equilibrium and soil maturity. In this respect, it resembles the climax pattern theory.

Even though the site climax and climax pattern theories are similar in basic philosophical concepts, they differ in their approach to fulfilling these concepts. The climax pattern theory follows the continuum approach while the site climax theory follows the discontinuous approach.

The meaning of original vegetation and man-caused eroded soils is important. Original vegetation, as used by Dyksterhuis, refers to the native plant population and excludes introduced species, whether they are naturalized or not.

In cases where a particular soil series has eroded or has had another major disturbance occur, such as the water table being lowered on a soil characterized by a high water table, the changed habitat affects the site climax plant association. It also affects that particular soil series, or phase, because it no longer has the same distinquishing characteristics. Thus, a phase of that soil series or a new soil series may need to be developed in order to reflect these changes. This will also reflect a change in the climax plant association; namely, the same site climax which occurred before disturbance is no longer capable of inhabiting the site. Therefore, the highest plant succession that is now capable of inhabiting this eroded soil is considered to be the climax for that site. Dyksterhuis (1958b) pointed out that climax vegetation for a site can be measured (quantitatively) to show the differences between sites resulting from different soils and climate.

\section{Climax and Classification Summary}

Of the 5 climax theories, only 2 appear to be compatible with today's need of delineating current vegetation in relation to its potential with consideration of trend. These are the climax pattern and site climax theories. These 2 are considered the best choices because neither requires maturity in soil development or geomorphological development for a plant community to be considered "climax". In contrast, the mono, poly, and polyclimatic theories require soil maturity. One of the major objectives of a classification is to provide management with a useful tool to know what and how much it is managing. For a classification to be most useful to management (i.e., resource managers), the most logical choice is the site climax approach. Site climax is already used widely with the USDA Soil Conservation Service and the USDI Bureau of Land Management and Bureau of Indian Affairs.

Determining the site climax vegetation may be difficult for some areas of the United States. Shiflet (1973) gave 5 methods to use to determine climax vegetation where it is absent:

1. Evaluate climax vegetation on associated soils subjected to minimal disturbance.

2. Compare areas receiving varying degrees of use with similar areas receiving no use.

3. Evaluate and interpret research dealing with natural plant communities and soils.

4. Review early historical and botanical literature.

5. Extrapolate existing vegetation information to areas of similar soils, climate, and microenvironment.

It is necessary to know the soil series (and phases when applicable) to place a plant community that has departed from climax in the correct site climax. If a plant community is in a low ecological stage, the only characteristic it may have in common with the site climax plant community is the soil series (and phase).

Although a classification should be based on climax vegetation, there is a need to know the current vegetation of an area. Information about the existing vegetation is necessary to establish ecological status and vegetation trend needed to make management decisions. Therefore, it is necessary to use the current vegetation in conjunction with climax vegetation classification. While no climax theory can be all things to all people, site climax as proposed appears to be a very logical choice as the basis for a classification system for management purposes.

\section{Literature Cited}

Bazzaz, F.A. 1979. The physiological ecology of plant succession. Ann. Rev. Ecol. and Syst. 10:351-371.

Braun-Blanquet, J. 1932. Plant sociology. Translated by G.D. Fuller and H.S. Conrad. McGraw-Hill, Inc. New York.

Cain, S.A. 1939. The climax and it complexities. Amer. Midl. Natur. 21:146-181.

Clements, F.E. 1916. Plant succession. Carnegie Inst. Publ. 242. Washington, D.C.

Clements, F.E. 1936. Nature and structure of the climax. J. Ecol. 24:253-284.

Cowles, H.C. 1899. The ecological relations of the vegetation on the sand dunes of Lake Michigan. Bot. Gaz. 27:95-116, 167-202, 281-308, 361-391.

Cowles, H.C. 1901. The physiographic ecology of Chicago and vicinity; a study of the origin, development, and classification of plant societies. Bot. Gaz. 31:73-108, 145-182.

Curtis, J.T., and R.P. McIntosh. 1951. An upland forest continuum in the prairie-forest border region of Wisconsin. Ecology 32:476-496.

Daubenmire, R. 1968. Plant communities, a textbook of plant synecology. Harper and Row, New York.

Domin, K. 1923. Is the evolution of the earth's vegetation tending towards a smaller number of climatic formations? Acta Bont. Bohemica 2:54-60.

Driscoll, Richard S., Daniel L. Merkel, David L. Radloff, Dale E. Snyder and James S. Hagihara. 1984. An ecological land classification framework for the United States. USDA Misc. Publ. No. 1439. Washington, D.C. In process.

DuRietz, G.E. 1930. Vegetationsforschung auf soziationsanalytischer Grundlage. Adherhalden, Handb. Biol. Arbeitsmeth 11:293-480.

Dyksterhuis, E.J. 1949. Condition and management of range land based on quantitative ecology. J. Range Manage. 2:104-115.

Dyksterhuis, E.J. 1958a. Ecological principles in range evaluation. Bot. Rev. 24:253-272.

Dyksterhuis, E.J. 1958b. Range conservation based on sites and condition classes. J. of Soil and Water Conserv. 13:104-115.

Ellenberg, H. 1959. Typen tropischer Urwalder in Peru. Schweiz Z. Forstw. 110:169-187.

Fosberg, F.R. 1967. A classification of vegetation for general purposes. 73-102 p. In: Guide to the Check Sheet for IBP Areas, G.F. Peterken (ed.). IBP Handbook No. 4. Blackwell Scientific Publ., Oxford.

Gleason, H.A. 1939. The individualistic concept of the plant association. Amer. Midl. Natur. 21:92-110.

Hall, F.C. 1970. An ecological classification proposal and its importance in land management. 210-216 p. In: USDA Forest Serv. Misc. Pub. 1147.

Krebs, C.J. 1972. Ecology, the experimental analysis of distribution and abundance. Harper and Row, New York.

MacMahon, J.A. 1980. Ecosystems over time: succession and other types of change. p. 27-57. In: Forests: Fresh Perspectives from Ecosystem Analysis, R.H. Waring (ed.). Proceedings of the 40th Ann. Biol. Colloquim. Oregon State Univ. Press, Corvallis.

Moss, C.E. 1913. Vegetation of the Peak District. Cambridge University Press, Mass.

Mueller-Dombois, D., and H. Ellenberg. 1974. Aims and methods of vegetation ecology. John Wiley and Sons, Inc. New York.

Odum, E.P. 1969. The strategy of ecosystem development. Science 164:262-270.

Odum, E.P. 1971. Fundamentals of ecology. W.B. Sanders Co., Philadelphia.

Shiflet, T.H. 1973. Range sites and soil in the United States. p. 26-33. In: Society for Range Manage. Publ., Arid Shrublands.

Shimwell, D.W. 1972. The description and classification of vegetation Univ. of Washington Press, Seattle.

Tansley, A.G. 1920. The classification of vegetation and the concept of development. J. Ecol. 8:118-149.

Tansley, A.G. 1929. Succession, the concept and its values. p. 677-686. In: Proc. Int. Congr. Plant Sci. Ithaca.

Tansley, A.G. 1939. (sec. ed.). The British Islands and their vegetation. Cambridge Univ. Press.

Tuxen, R. 1933. Klimaxprobleme des nordwesteuropaischen Festlandes. Nederl. Kriudkund. Arch. 43:293-309.

Tuxen, R., and H. Diemont, 1937. Klimaxgruppe and Klimaxschwarm. Jahresber. Naturhist. Ges. Hannover 88/89:73-87.

United Nations Educational, Scientific, and Cultural Organization. 1973. International classification and mapping of vegetation. Paris. 
USDA, Forest Service. 1979. Forest Service manual 2200- range management. Washington, D.C. (mimeo)

USDA, Soil Conservation Service. 1976. Range handbook. Washington, D.C.

USDI, Bureau of Indian Affairs. 1958. Handbook for making resource inventories. Washington, D.C.

USDI, Bureau of Land Management. 1978. Soil-vegetation inventory method. Washington, D.C.

Weaver, J.E., and F.E. Clements. 1938. Plant ccology. McGraw-Hill, Inc., New York.
Whittaker, R.H. 1951. A criticism of the plant association and climatic climax concepts. Northwest Sci. 25:17-31.

Whittaker, R.H. 1953. A consideration of climax theory: The climax as a population and pattern. Ecol. Monogr. 23:41-78.

Whittaker, R.H. 1956. Vegetation of the Great Smoky Mountains. Ecol. Monogr. 26:1-80.

Whittaker, R.H. 1967. Gradient analysis of vegetation. Biol. Rev. 49:207264. 